DOI: https://doi.org/10.47405/mjssh.v5i11.616

\begin{tabular}{|c|c|}
\hline 4 & Malaysian Journal of Social Sciences and Humanities (MJSSH) \\
\hline Malaysian Journal of & Volume 5, Issue 11, November 2020 \\
\hline $\begin{array}{l}\text { Humantives } \\
\text { (MJ SsH })\end{array}$ & e-ISSN : 2504-8562 \\
\hline & $\begin{array}{l}\text { Journal home page: } \\
\text { www.msocialsciences.com }\end{array}$ \\
\hline
\end{tabular}

\title{
Analisis Appraisal Mengenai Keterlibatan Generasi Muda FELDA dalam Industri Kelapa Sawit
}

\author{
Fuzirah Hashim ${ }^{1}$, Kesumawati A. Bakar' ${ }^{\text {, Siti Hamin Stapa }}{ }^{1}$ \\ ${ }^{1}$ Center for Research in Language and Linguistics, Universiti Kebangsaan Malaysia (UKM) \\ Correspondence: Fuzirah Hashim (fuzy@ukm.edu.my)
}

\begin{abstract}
Abstrak
Sebagai penyumbang keempat terbesar kepada ekonomi negara Malaysia, industri kelapa sawit telah menunjukkan kemajuan yang ketara dan perkembangan yang pesat sejak beberapa dekad yang lalu. Walaupun terdapat usaha yang bersepadu untuk mempromosikan dan mewujudkan kesedaran di kalangan belia sektor ini, kebanyakan golongan muda tidak berminat untuk berkhidmat dalam industri ini, malah memilih untuk bekerja di sektor perkilangan dan runcit. Mengguna pakai Teori Systemic Functional Linguistics Appraisal khususnya sistem Attitude, artikel ini membentangkan analisis linguistik makna interpersonal yang diungkapkan oleh 5 orang belia FELDA ke arah penglibatan industri minyak sawit. Kajian ini meneliti keterlibatan dan minat golongan belia dan bagaimana kekuatan dan kelemahan industri ini ditonjolkan melalui analisis wacana. 5 wawancara dianalisis dan dikodkan dari segi Affect, Judgement dan Appreciation. Dapatan kajian menunjukkan bagaimana setiap responden menyampaikan penilaian positif dan negatif terhadap industri dan tingkah laku masyarakat FELDA. Dapatan ini juga memaparkan tiga bidang kekuatan dan kelemahan yang melibatkan kemapanan industri dan sumbangan sosio-ekonomi yang penting kepada komuniti FELDA. Walaupun penilaian cenderung kepada nilai positif, kebanyakan responden merasa tidak puas hati terhadap sektor ini. Mereka menyarankan kaedah baru melalui teknologi dan media sosial untuk menarik minat golongan belia terhadap industri kelapa sawit.
\end{abstract}

Kata kunci: appraisal, attitude, systemic functional linguistics, belia, industri kelapa sawit

\section{Appraisal Analysis of FELDA Youths' Involvement in the Palm Oil Industry}

\begin{abstract}
As the fourth largest contributor to the Malaysian economy, the oil palm industry has shown significant progress and rapid development over the past few decades. While there are concerted efforts to promote and create awareness among the youths of this sector, most young people are not interested to serve in the industry, instead choosing to work in the manufacturing and retail sectors. Applying Systemic Functional Linguistics Appraisal Theory, especially Attitude system, this paper presents a linguistic analysis of interpersonal meanings expressed by 5 FELDA youths towards the palm oil industry involvement. This study examines the involvement and interests of youth and how the strengths and weaknesses of this industry are highlighted through discourse analysis. 5 interviews were analyzed and coded in terms of Affect, Judgment and Appreciation. The findings of the study show how each respondent presented the positive and negative assessment of the industry as well as the behavior of the FELDA community. These findings also showcase three areas of strengths and weaknesses involving the industry's sustainability and important socio-economic contribution to the
\end{abstract}


FELDA community. Despite the positive evaluation, most respondents displayed disinterest in the sector, by proposing new methods through technology and social media to attract youths to the palm oil industry.

Keywords: appraisal, attitude, systemic functional linguistics, youth, palm oil industry

\section{Pengenalan}

Industri kelapa sawit merupakan penyumbang keempat terbesar kepada ekonomi dan agroindustri negara. Industri ini telah menunjukkan kemajuan yang ketara dan memberi sumbangan yang besar kepada pengeluaran dan eksport minyak sawit dunia (Ferdous, Er \& Halima, 2015). Namun begitu, perkembangan pesat industri ini telah menimbulkan banyak isu, di antaranya adalah pergantungan terhadap pekerja asing di sektor perladangan. Walaupun terdapat usaha yang bersepadu untuk mempromosikan dan mewujudkan kesedaran tentang potensi industri ini di kalangan belia, kebanyakan mereka tidak berminat untuk bekerja di ladang. Malah, mereka lebih cenderung untuk memilih sektor pertanian sebagai pilihan ketiga selepas sektor perkilangan dan runcit (Statistik Sumber Manusia Malaysia 2013).

Beberapa kajian telah menunjukkan bahawa sejumlah besar belia di Malaysia mempunyai persepsi negatif terhadap industri minyak kelapa sawit disebabkan oleh tenaga kerja yang berat, kepuasan kerja yang rendah dan keadaan pekerjaan yang tidak memberangsangkan. Kajian oleh Roslina et al. (2016) melaporkan bahawa persekitaran tempat kerja yang dianggap tidak menarik dan kotor, membuatkan belia kurang minat untuk menyertai industri ini. FELDA dalam usaha untuk menghapuskan kemiskinan, telah pun menyediakan kemudahan yang mencukupi dalam memastikan peningkatan tahap sosio-ekonomi dan kualiti hidup mereka. Walaupun terdapat usaha yang berpanjangan untuk meningkatkan jumlah penglibatan belia dalam industri minyak sawit, mereka masih tidak menunjukkan minat yang tinggi untuk melibatkan diri dalam industri ini.

Sikap positif dan negatif adalah penting untuk menerangkan dan meramal tingkah laku setiap individu. Namun, hubungan antara sikap dan tingkah laku sering menimbulkan kontroversi. Kebanyakan kajian empirikal menyokong hubungan positif antara sikap dan tingkah laku, tetapi korelasinya adalah antara kecil hingga sederhana. Ini adalah kerana terdapat banyak pemboleh ubah, keadaan dan kekangan yang menyebabkan percanggahan sikap dan tingkah laku (Ajzen, 1993; Eagly \& Chaiken, 1993; McGuire, 1985). Dapatan kajian secara umumnya telah menyimpulkan bahawa sikap mungkin merupakan petunjuk yang baik terhadap tingkah laku manusia (McGuire, 1985; Ajzen \& Fishbein, 1980). Ini bermakna pengetahuan tentang sikap boleh membantu dalam meramalkan kelakuan masa depan di kalangan individu.

Kajian ini dijalankan untuk mengenal pasti sikap dan persepsi belia FELDA terhadap pelbagai aspek dalam industri minyak sawit. Dengan memahami lebih lanjut mengenai sikap mereka, kesimpulan boleh dibuat mengenai hubungan antara sikap dan tingkah laku yang membentuk, mengubah dan mempengaruhi cara mereka berkelakuan. Objektif kedua kajian ini adalah untuk mendapatkan pandangan tentang faktor-faktor yang menyumbang kepada sikap positif dan negatif di kalangan generasi muda FELDA terhadap industri minyak kelapa sawit. Mengkaji persepsi para belia adalah penting kerana mereka adalah generasi akan datang yang lebih terpelajar, dan diharapkan akan menjadi individu yang berinovasi dan bertanggungjawab untuk meneruskan warisan FELDA.

Kajian ini memberi tumpuan kepada pilihan bahasa (linguistik) yang digunakan oleh 5 orang responden belia FELDA dalam memberi jawapan kepada temu bual mengenai industri minyak sawit, dan bagaimana pilihan yang dibuat memperlihatkan penilaian interpersonal mengenai pelbagai aspek industri dan masyarakatnya. Menggunakan Sistem Appraisal (Martin \& White 2005), kajian ini meneliti sikap generasi muda FELDA dan bagaimana ia memperlihatkan kekuatan dan kelemahan amalan semasa industri. Lima temu bual dianalisis dan dikodkan dari segi Affect, Judgement dan 
Appreciation, untuk mengenal pasti cara responden menyampaikan penilaian positif dan negatif terhadap industri dan tingkah laku peneroka.

\section{Sorotan Literatur}

Kebanyakan teori mengenai sikap (attitude) menjelaskan bahawa sikap merangkumi tiga komponen, iaitu kognisi, pengaruh dan kecenderungan tingkah laku. Kognisi merupakan kepercayaan, pendapat, pengetahuan atau maklumat yang dipegang oleh seseorang terhadap sesuatu objek melalui ekspresi lisan dan reaksi bukan lisan. Komponen afektif adalah segmen emosional di mana respons melibatkan ekspresi verbal terhadap objek serta reaksi fisiologi, ekspresi wajah dan indikator bukan lisan yang berbentuk positif atau negatif. Akhir sekali, kecenderungan tingkah laku merujuk kepada rancangan, niat dan komitmen, serta tindakan yang melibatkan sikap terhadap objek (Ajzen, 1993).

Menurut Gardner 'sikap adalah tindak balas evaluatif terhadap objek rujukan dan objek sikap, berdasarkan kepercayaan atau pendapat seseorang' (Gardner, 1985). Pendapat ini dikongsi oleh Martin dan Rose (2003) yang mendefinisikan sikap sebagai sumber yang digunakan untuk menyatakan penilaian positif atau negatif terhadap tingkah laku manusia, proses, benda hidup dan bukan hidup, keadaan dan emosi. Baker (1988) merumuskan ciri-ciri utama sikap sebagai kognitif (berfikir) dan afektif (emosi) dan berbeza-beza dalam tahap kepuasan/ketidakpuasan. Ia dipelajari dan tidak boleh diwarisi, tetapi boleh berubah mengikut pengalaman. Sikap dapat mempengaruhi seseorang untuk bertindak dengan cara tertentu, tetapi hubungan antara sikap dan tindakan adalah lemah. Dalam kajian ini, rujukan kepada sikap adalah sebagai tindak balas positif atau negatif kepada individu, objek, seseorang atau keadaan yang berkaitan dengan aspek industri minyak sawit seperti persekitaran kerja, pengurusan, isu buruh dan ganjaran.

\section{Sikap terhadap perladangan dan industri kelapa sawit}

Sebilangan kecil kajian telah mengkaji hubungan antara sikap, motivasi dan kepuasan dalam sektor pertanian dan perladangan di kalangan belia Malaysia (Roslina et al., 2016; Norehan, 2016; Mohamad Amizi et al., 2016; Norsida, 2008). Didapati bahawa kebanyakan belia pinggir bandar tempatan lebih suka bekerja di sektor pembuatan dan runcit daripada sektor pertanian dan perladangan (Malaysia Human Resource Statistic, 2013). Mereka mendakwa bahawa pekerjaan di sektor pertanian membebankan dan meletihkan (Norsida, 2008). Ini disokong oleh kajian Walsh dan Makaravy (2011) yang melaporkan bahawa pekerjaan perladangan dianggap sebagai pekerjaan 3D (Difficult, Dirty and Dangerous- Sulit, Kotor dan Berbahaya) oleh belia tempatan. Kajian lepas telah menunjukkan persepsi dan sikap negatif yang kuat di kalangan belia tempatan dan sebab-sebab yang mendasari sikap negatif mereka. Menurut Frick et al. (1995), belia mendapati bahawa sektor pertanian tidak menarik kerana kurangnya pengetahuan atau kemahiran. Selain itu, masalah sosial seperti penyalahgunaan dadah dan perlumbaan motor haram juga menjauhkan mereka dari sektor ini (Saifuddin, 2017).

Siti, Kesumawati dan Fuzirah (2018) telah melakukan tinjauan untuk mengenal pasti sikap di kalangan generasi muda FELDA terhadap industri kelapa sawit di Malaysia. Hasilnya menunjukkan bahawa secara umum, generasi muda FELDA mempunyai sikap positif terhadap industri kelapa sawit. Mereka menyedari betapa pentingnya industri ini dan mereka mempunyai keinginan untuk menyumbang ke arah kemajuan industri ini. Hasil kajian juga menunjukkan bahawa pekerja mempunyai kedua-dua sikap dan motivasi positif dan negatif terhadap industri. Walau bagaimanapun, aspek positif melebihi yang negatif. Penyelidikan ini melaporkan kedudukan 8 konstruk yang didapati positif di kalangan responden terhadap industri kelapa sawit. Status sosial berada di kedudukan tertinggi (3.31), diikuti oleh pengurus (3.24), keserasian dalam industri (3.18), rakan sekerja (3.13), sifat pekerjaan $(3,07)$, keadaan fizikal di tempat kerja (3.02), komitmen (2.91) dan akhirnya peluang promosi (2.84).

Status sosial berada di kedudukan tertinggi, menunjukkan bahawa responden yakin bahawa keluarga mereka bangga dengan profesion mereka dalam industri kelapa sawit. Selain itu, mereka percaya bahawa bekerja di industri kelapa sawit adalah pekerjaan yang dihormati di Malaysia. Responden juga bersetuju bahawa pengurus selalu menghargai pekerja mereka dan berusaha keras untuk menyokong 
mereka dalam perkembangan kerjaya. Pengurus bijak mengagihkan kerja dan selalu menghargai cadangan serta bersikap hormat terhadap pekerja. Responden juga melaporkan pengurus sentiasa memastikan pekerja mengambil bahagian dalam keputusan yang mempengaruhi pekerjaan mereka dan memberikan latihan yang sesuai apabila perlu.

Literatur di atas membincangkan sikap generasi muda terhadap industri kelapa sawit. Kajian ini pula akan mengkaji persepsi di kalangan generasi muda FELDA mengenai industri kelapa sawit. Responden ditemu ramah untuk mengetahui sikap mereka terhadap industri dan temu ramah ini kemudiannya dianalisis menggunakan Appraisal analisis. Bahagian seterusnya membincangkan instrumen yang digunakan untuk menganalisis ekspresi sikap belia FELDA.

\section{Menganalisis EkspresiSikap Pemuda FELDA}

Kerangka Attitude (Martin \& White, 2005) diadopsi dalam kajian ini untuk menganalisis sumber lisan yang digunakan dalam temu bual kumpulan fokus untuk menilai industri kelapa sawit. Attitude adalah sistem makna interpersonal yang menawarkan kerangka analisis untuk mengenal pasti dan mengklasifikasikan ekspresi sikap secara sistematik. Fokus analisis sikap dalam kajian ini adalah pada ekspresi emosi secara terus (langsung) dan tidak langsung, penilaian tingkah laku dan penilaian entiti, prestasi dan keadaan dan fenomena semula jadi. Bahagian berikutnya menerangkan sistem Attitude yang telah dibangunkan oleh Martin (2000, 2003) dan Martin dan White (2005).

\section{Attitude (Sikap)}

Ekspresi Attitude dapat dikategorikan kepada 3 jenis yang berbeza - Affect (ekspresi emosi), Judgement (penilaian tingkah laku) dan Appreciation (penilaian sesuatu). Contoh setiap jenis sikap diberikan menggunakan contoh dari temu bual. Bahagian berikut akan menerangkan setiap jenis sikap bersama dengan konvensyen anotasinya dari Martin dan White (2005) yang digunakan dalam analisis.

Perbezaan pertama dibuat antara ungkapan positif [+] dan negatif [-]. Dalam contoh berikut, kata-kata dalam huruf tebal dinyatakan sebagai mewakili nilai positif atau negatif (ditunjukkan dalam tanda kurung).

\section{Saya amat berminat $[+]$}

\section{Remaja kita bermasalah [-]}

Langkah seterusnya dalam mengklasifikasikan ekspresi sikap adalah mengklasifikasikannya mengikut Affect, Judgement atau Appreciation (Martin \& White, 2005).

\section{Affect}

Affect adalah berkaitan dengan ekspresi perasaan dan dapat diklasifikasikan mengikut lima soalan berikut: Adakah perasaan itu positif atau negatif ?; Adakah perasaan itu akibat lonjakan emosi atau keadaan mental yang dialami ?; Adakah perasaan itu ditujukan kepada atau bertindak balas terhadap sesuatu yang bertentangan dengan perasaan hati yang dialami ?; Adakah perasaan melibatkan niat untuk rangsangan yang tidak realistik (iaitu melibatkan pencetus) ?; dan Adakah perasaan realistik (iaitu keadaan atau perasaan terarah) ada kaitannya dengan ketidakbahagiaan, kebahagiaan, tidak rasa selamat, keselamatan atau tidak puas hati dan kepuasan hati? Jadual 1 menunjukkan contoh realiti yang mempengaruhi seperti ketidakbahagiaan, kebahagiaan, tidak rasa selamat, keselamatan, tidak puas hati dan kepuasan hati. 

DOI: https://doi.org/10.47405/mjssh.v5i11.616

Jadual 1: Affect Realis (Martin \& White, 2005: 49-51)

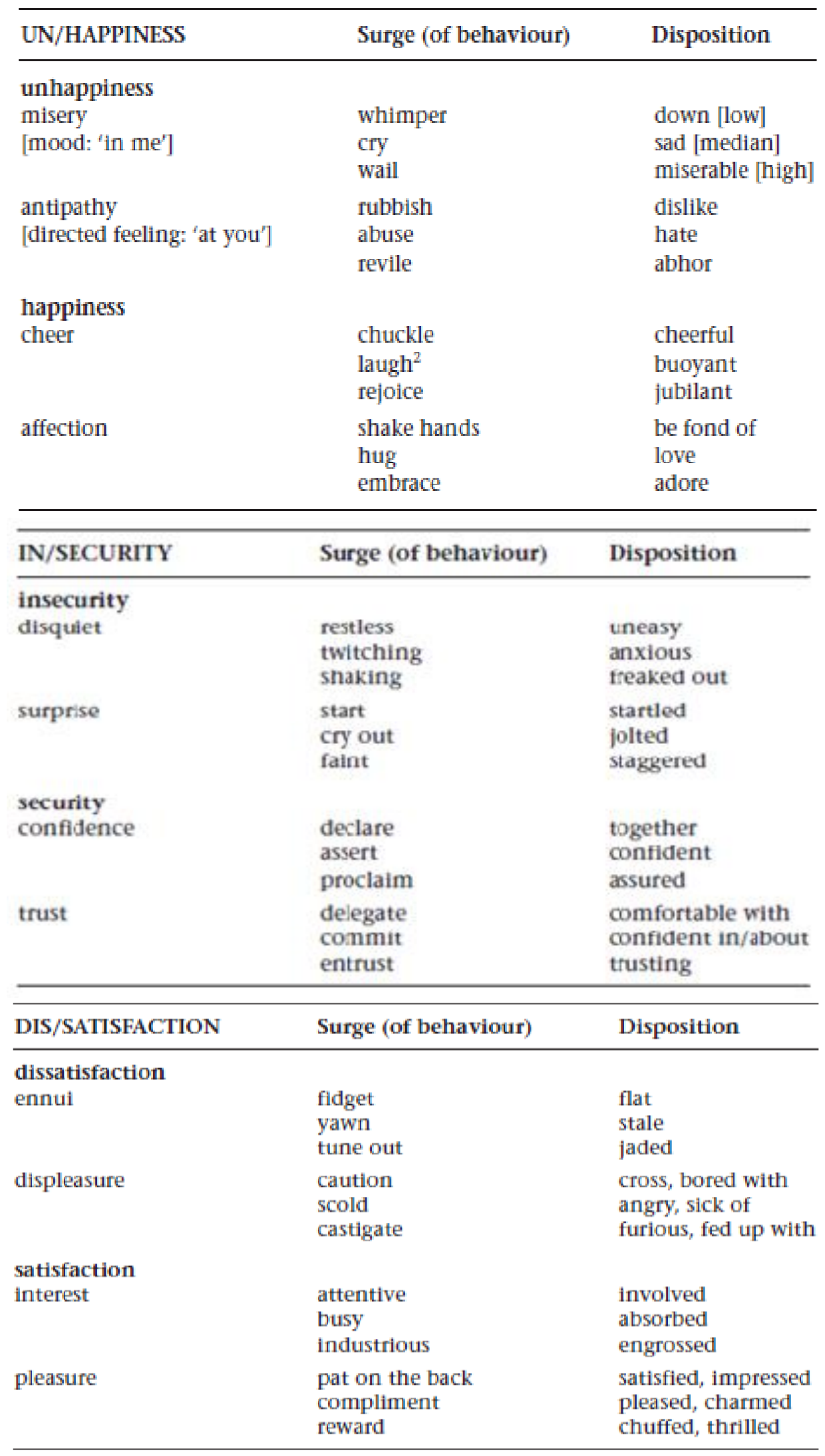


Mengikuti konvensyen Martin dan White (2005), singkatan yang digunakan untuk Affect adalah seperti berikut:

$$
\begin{array}{ll}
\text { des } & \text { 'affect: desire' } \\
\text { hap } & \text { 'affect: un/happiness' } \\
\text { sec } & \text { 'affect: in/security' } \\
\text { sat } & \text { 'affect: dis/satisfaction' }
\end{array}
$$

Emosi sering diluahkan untuk menggambarkan kecenderungan dan reaksi positif dan negatif terhadap seseorang, sesuatu aktiviti dan perkara. Berikut merupakan contoh kesan positif dan negatif yang diambil dari data, dengan kesan dalam huruf tebal dan bergaris bawah.

$$
\text { Saya amat berminat }[+ \text { sat] }
$$

\section{Judgement}

Judgement secara khusus merujuk pada penilaian sikap terhadap tingkah laku manusia, yang dapat dibezakan antara "penilaian peribadi tentang kekaguman atau kritikan dan penilaian moral atas pujian atau kecaman" (Martin \& Rose, 2003). Penilaian peribadi tentang kekaguman atau kritikan disebut penghargaan sosial (social esteem) dan selanjutnya diklasifikasikan sebagai penilaian normal (betapa luar biasa atau istimewa seseorang itu), kemampuan (berapa mampu seseorang itu) dan ketabahan (berapa tegas seseorang itu). Penghakiman moral pujian dan kecaman dilabelkan sebagai sekatan sosial. Seterusnya ia diklasifikasikan sebagai penilaian ketulusan (betapa jujur seseorang itu) dan kesopanan (bagaimana beretika seseorang itu) (Martin \& White, 2005). Berikut adalah singkatan bagi jenis-jenis Judgement.

$\begin{array}{ll}\text { norm } & \text { 'judgement: normality' } \\ \text { cap } & \text { 'judgement: capacity' } \\ \text { ten } & \text { 'judgement: tenacity' } \\ \text { ver } & \text { 'judgement: veracity' } \\ \text { prop } & \text { 'judgement: propriety' }\end{array}$

Seperti juga Affect, Judgement dapat dinilai secara negatif atau positif. Berikut adalah contoh penilaian positif dan negatif yang terdapat dalam data. Realisasi Judgement ditulis dalam huruf tebal dan bergaris bawah.

\section{Remaja kita bermasalah [-cap]}

\section{Appreciation}

Appreciation biasanya melibatkan penilaian keberlanjutan, keberkesanan dan kebaikan industri, misalnya :

\section{Industri ini telah bertahan sejak dahulu sehingga sekarang dan telah membantu banyak generasi kita.}

Sistem Appreciation diselenggarakan di sekitar tiga pemboleh ubah: reaksi, komposisi dan penilaian (Martin \& White, 2005). Martin \& White (2005) menjelaskan bahawa: "Dengan Appreciation kita beralih kepada makna yang mentafsirkan penilaian terhadap 'perkara' terutama perkara yang kita buat dan perlaksanaannya, juga merangkumi fenomena semula jadi - setimpal dengan nilainya (bagaimana kita menghargainya). Secara umum Appreciation dapat dibahagikan kepada 'reaksi' kita terhadap sesuatu perkara (adakah ianya menarik perhatian kita; adakah ia menggembirakan kita?), 'Komposisi' 
mereka (keseimbangan dan kerumitan), dan 'nilai' mereka (betapa inovatif, autentik, tepat pada masanya , dan lain-lain)."

Seperti Affect dan Judgement, Appreciation dapat dinilai secara negatif atau positif. Jadual 2 menunjukkan pelbagai jenis Appreciation dan contohnya.

Jadual 2. Jenis Appreciation (Martin \& White 2005: 56).

\begin{tabular}{|c|c|c|}
\hline Reaction: & arresting, captivating, engaging ...; & dull, boring, tedious ....; \\
\hline $\begin{array}{l}\text { impact 'did it } \\
\text { grab me?' }\end{array}$ & $\begin{array}{l}\text { fascinating, exciting, moving ...; } \\
\text { lively, dramatic, intense ...; } \\
\text { remarkable, notable, sensational ... }\end{array}$ & $\begin{array}{l}\text { dry, ascetic, uninviting .... } \\
\text { flat, predictable, monotonous .... } \\
\text { unremarkable, pedestrian ... }\end{array}$ \\
\hline $\begin{array}{l}\text { Reaction: } \\
\text { quality 'did I like it?' }\end{array}$ & $\begin{array}{l}\text { okay, fine, good .... } \\
\text { lovely, beautiful, splendid ...; } \\
\text { appealing, enchanting, welcome ... }\end{array}$ & $\begin{array}{l}\text { bad, yuk, nasty ....; } \\
\text { plain, ugly, grotesque ...; } \\
\text { repulsive, revolting, off-putting ... }\end{array}$ \\
\hline $\begin{array}{l}\text { Composition: } \\
\text { balance 'did it hang } \\
\text { together?' }\end{array}$ & $\begin{array}{l}\text { balanced, harmonious, unified, } \\
\text { symmetrical, proportioned ...; } \\
\text { consistent, considered, logical ...; } \\
\text { shapely, curvaceous, willowly ... }\end{array}$ & $\begin{array}{l}\text { unbalanced, discordant, irregular, } \\
\text { uneven, flawed ...; } \\
\text { contradictory, disorganised ...; } \\
\text { shapeless, amorphous, distorted ... }\end{array}$ \\
\hline $\begin{array}{l}\text { Composition: } \\
\text { Complexity } \\
\text { 'was it hard to follow?' }\end{array}$ & $\begin{array}{l}\text { simple, pure, elegant ...; } \\
\text { lucid, clear, precise ...; } \\
\text { intricate, rich, detailed, precise ... }\end{array}$ & $\begin{array}{l}\text { ornate, extravagant, byzantine ....; } \\
\text { arcane, unclear, woolly ...; } \\
\text { plain, monolithic, simplistic ... }\end{array}$ \\
\hline $\begin{array}{l}\text { Valuation } \\
\text { 'was it worthwhile?' }\end{array}$ & $\begin{array}{l}\text { penetrating, profound, deep ...; } \\
\text { innovative, original, creative ...; } \\
\text { timely, long awaited, landmark ...; } \\
\text { inimitable, exceptional, unique ...; } \\
\text { authentic, real, genuine ...; } \\
\text { valuable, priceless, worthwhile ...; } \\
\text { appropriate, helpful, effective ... }\end{array}$ & $\begin{array}{l}\text { shallow, reductive, insignificant ...; } \\
\text { derivative, conventional, prosaic ...; } \\
\text { dated, overdue, untimely ...; } \\
\text { dime-a-dozen, everyday, common; } \\
\text { fake, bogus, glitzy ...; } \\
\text { worthless, shoddy, pricey ...; } \\
\text { ineffective, useless, write-off ... }\end{array}$ \\
\hline
\end{tabular}

Berikut adalah singkatan bagi jenis-jenis Appreciation

reac 'appreciation: reaction'

comp. 'appreciation:composition'

val 'appreciation: valuation'

Berikut adalah contoh penilaian yang dibuat oleh salah seorang responden, dalam huruf tebal bergaris bawah.

Industri ini telah bertahan sejak dahulu sehingga sekarang [+ val] dan telah membantu banyak generasi kita [+ val].

Adalah wajar untuk mengambil perhatian bahawa subjektiviti pengekodan Appraisal adalah disebabkan oleh pembacaan konteks dan teks di mana wujudnya leksis sikap. Untuk menentukan kategori sikap, adalah perlu untuk melihat apa yang dinilai dalam klausa (siapa yang dinilai atau apa yang dinilai). Bahagian seterusnya membincangkan tentang responden dan metodologi yang digunakan untuk pengumpulan data.

\section{Metod Kajian}

Kajian kualitatif ini mengaplikasikan temu bual kumpulan fokus untuk mengumpul data. Data adalah berdasarkan kepada lima sesi temu bual yang berlangsung di Fakulti Sains Sosial dan Kemanusiaan, Universiti Kebangsaan Malaysia, Selangor. Lima orang responden yang ditemu bual merupakan generasi ketiga peneroka FELDA. Temu bual kumpulan fokus dijalankan sebanyak dua kali; yang pertama dijalankan dengan dua orang pelajar dan yang kedua dengan tiga orang pelajar. Temu bual tersebut tidak dapat dijalankan dalam satu sesi serentak memandangkan pelajar mempunyai jadual 
akademik yang berbeza. Tempoh temu bual keseluruhannya adalah selama 150 minit. 5 orang responden yang ditemu bual iaitu Farah, Aina, Liana, Atikah dan Syahirah adalah pelajar Tahun Dua di Fakulti Sains Sosial dan Kemanusiaan, berumur 21 tahun. Parameter untuk pemilihan telah dipersetujui kerana mereka mewakili penempatan FELDA yang berbeza. Ini adalah penting untuk mendapatkan pengalaman dan pendapat yang berbeza dari pelbagai latar belakang mereka.

Temu bual tersebut dirakam secara audio dan kemudian ditranskripsikan. Transkripsi dikodkan dan kewujudan Attitude (Affect, Judgement dan Appreciation) dihitung. Pengekodan data cuba mencerminkan sedekat mungkin sudut pandangan responden. Ianya berdasarkan kepada item leksikal (sebagai contoh, 'saya berminat kalau ada peluang pekerjaan' ); bukannya diambil daripada komunikasi bukan lisan. Oleh itu, tawa dan ciri-ciri bukan lisan lain tidak disertakan.

Bahagian seterusnya meneliti bagaimana makna sikap calon menunjukkan penilaian positif dan negatif dari pelbagai aspek industri kelapa sawit.

\section{Hasil Kajian dan Perbincangan}

Berdasarkan teori Systemic Functional Linguistics Appraisal khususnya sistem Attitude, artikel ini mengkaji temu bual kumpulan fokus 5 orang pelajar FELDA di mana mereka telah menyampaikan pendapat dan tanggapan mereka terhadap industri minyak sawit tempatan. Analisis data dari lima temubual tersebut telah pun menunjukkan 58 ekspresi Attitude: 8 ekspresi Affect, 10 Judgemental dan 40 Appreciation. $60 \%$ dari ekspresi Judgemental didapati secara langsung dan kebanyakan ungkapan Affect (86\%) dirakam, begitu juga dengan Appreciation yang sebahagian besarnya dirakam (66\%) (Lihat Rajah 1).

Rajah 1. Taburan Sikap Positif dan Negatif dalam Temu bual

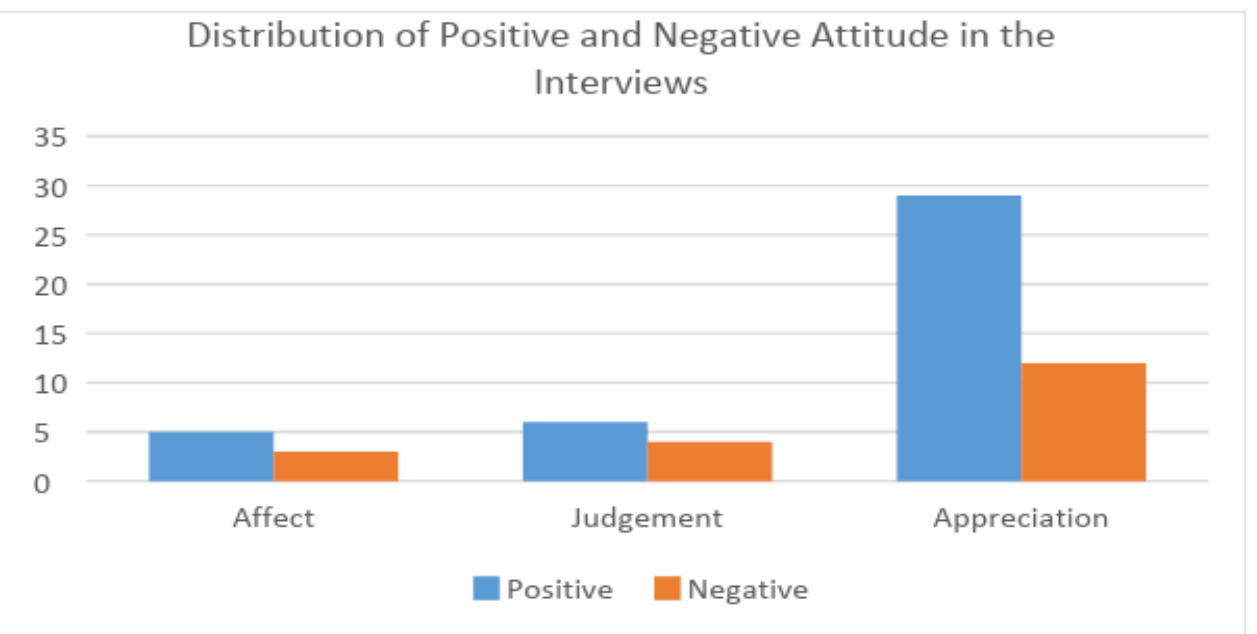

Secara keseluruhan, mereka yang ditemu bual menyampaikan penilaian yang lebih positif daripada penilaian negatif. Maklum balas yang diberikan menyumbang kepada korpus yang mengandungi 40 ekspresi positif dan 18 negatif. Daripada jumlah tersebut, terdapat 5 ungkapan emosi positif, berbanding 3 ungkapan negatif. Responden kebanyakannya menilai tingkah laku mereka sendiri dan yang lain secara positif: hanya 4 Judgement dari 10 yang negatif. Responden juga lebih cenderung untuk menaksir nilai industri secara positif dengan 29 sikap positif berbanding 12 negatif. Ini sejajar dengan penemuan terbaru kami dari tinjauan terhadap 50 pekerja FELDA yang menunjukkan sikap positif terhadap pelbagai aspek industri ( Siti et al., 2019; Fuzirah et al., 2019).

Perbandingan sepanjang temu bual menunjukkan bahawa Atikah mengaplikasikan Attitude lebih tinggi daripada calon lain - 2 kali ganda lebih banyak daripada Farah, Syahirah dan Aina (pengguna terendah). Atikah membuat Judgement 3-5 kali lebih banyak daripada yang lain dan lebih menghargai aspek dan prestasi daripada yang lain. Dalam menjawab 6 soalan tersebut, kesemua responden 
menggunakan pelbagai jenis makna sikap, di mana Atikah telah membuat Judgement dan Appreciation paling banyak berbanding dengan yang lain. Liana, sebaliknya, tidak membuat Judgement langsung (lihat Rajah 2). Maklum balas mereka menyoroti tiga bidang di mana penilaian responden memainkan peranan penting dalam menonjolkan kekuatan dan kelemahan industri dan masyarakatnya: 1) nilai berkaitan dengan faedah, potensi dan pengiktirafan dan 2) nilai berhubung dengan keadaan kerja yang sukar dan pekerjaan yang dianggap kurang mahir 3) penghakiman berkaitan dengan generasi muda dan kurangnya minat dan kesedaran mereka mengenai potensi industri. Bahagian seterusnya akan menyampaikan analisis terperinci mengenai respons mereka terhadap setiap soalan.

Rajah 2. Pembahagian Sumber Attitudinal Responden dalam Temu bual

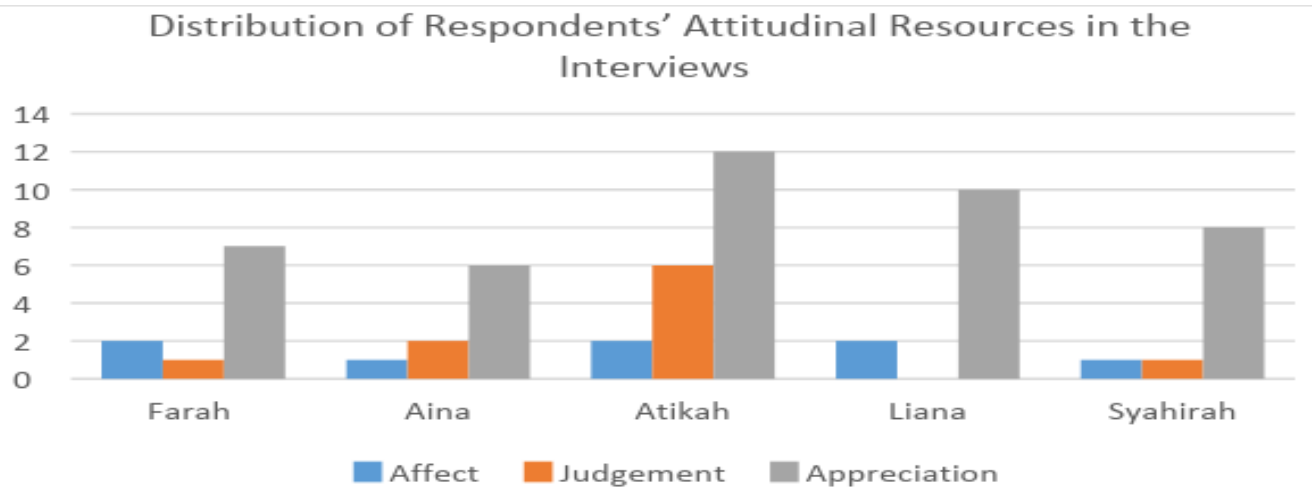

\section{Persepsi dan Sikap Terhadap Industri Kelapa Sawit}

Bahagian ini membincangkan hasil temu bual yang dijalankan. Enam soalan berkaitan dengan dimensi industri yang berbeza merangkumi kekuatan dan kelemahan, potensi masa depan dan penglibatan belia dijawab oleh responden. Mereka telah memberi pendapat mereka dan berkongsi pengalaman mereka sebagai sebahagian daripada komuniti FELDA. Analisis ini menghuraikan bagaimana makna sikap responden membina kekuatan dan kelemahan yang berbeza dalam industri dan komuniti.

\section{Soalan 1: Apakah kelebihan dan kekurangan industri kelapa sawit?}

Responden telah memberi ulasan positif terhadap industri dari segi Penilaian (betapa berbaloi) dan Pengaruh (minat). Kelima-lima responden menyampaikan penilaian positif terhadap industri dengan merujuk kepada kelestarian dan kelebihan ekonominya kepada negara dan masyarakat FELDA (11 contoh). Tiga daripada mereka bersetuju bahawa industri telah membantu menyumbang dan meningkatkan pendapatan peneroka, dengan itu memberi keyakinan kepada mereka mengenai kecukupan keperluan harian. Sebagai contoh, Liana memberi komen bahawa:

"Mesti pendapatan isi rumah tu akan bertambah [+ val] Contohnya, macam kawan saya bila tibanya musim kelapa sawit dia.. keluarga dia tak perlu risau [+ sec] bagaimana untuk macam mana nak dapat apa ni bekalan harian"

Dari segi kelestarian industri, tanggapan berikut diberikan oleh Farah dan Aina.

Farah: "Kekuatan industri kelapa sawit di Malaysia yang pertamanya kekal la daripada dulu sampai sekarang [+ val] daripada generasi atuk nenek sampai la saya"

Aina: "Industri ini dah kekal daripada dulu sampai sekarang [+val] dan dah banyak membantu generasi kami" [+ val]

Berdasarkan kepada respons tersebut, dapat disimpulkan bahawa kekuatan industri ini adalah kelestarian dan tempohnya yang panjang, yang telah membantu dan memanfaatkan beberapa generasi peneroka. Atikah menambah dengan menyatakan bahawa minyak sawit digunakan dalam pelbagai 
produk komersial seperti makanan dan ini menyebabkan permintaan berterusan terhadapnya. Ini telah membuka peluang pekerjaan kepada penduduk tempatan sama ada di ladang kelapa sawit atau industri pinggirannya.

“dia boleh mengeluarkan keluaran yang pelbagai [+ val] terutamanya dalam makanan. Kelapa sawit tu mempunyai permintaan yang tinggi untuk emm membuat sesuatu produk"[+val]

Bahagian seterusnya membincangkan Affect, khususnya perasaan dan pilihan responden berkaitan dengan penglibatan mereka dalam industri minyak sawit.

\section{Soalan 2: Apa yang anda suka dan tidak suka mengenai keterlibatan dalam industri ini?}

Semasa menganalisis soalan ini, kami mendapati bahawa responden ada kalanya menyatakan suka dan ada kalanya tidak suka dengan keterlibatan dalam industri sebagai sebahagian daripada komuniti FELDA. Responden menggunakan pelbagai sumber Attitudinal positif. Mereka menyatakan kesan positif dari segi kebahagiaan dan kepuasan; mereka juga terarah kepada penghakiman positif tentang kebiasaan, kemampuan dan kesesuaian. Yang paling kerap adalah penilaian industri dari segi faedah ekonominya, peluang pekerjaan dan pengurusan yang sistematik.

Dalam contoh berikut, Farah mengimplikasikan Affect positif kebahagiaan melalui penilaian hubungan positif apabila dia berkata: "Kita akan berjumpa dengan jiran-jiran kita so suasana tu di situ juga dapat
mengekalkan lagi. la menguatkan lagi silaturahim"( $[+\mathrm{val}][\mathrm{t},+$ hap $])$

Dia memberitahu tentang hubungan baik di antara para peneroka, mewujudkan persekitaran yang mesra yang mengeratkan hubungan. Aina menjelaskan dengan lebih lanjut mengenai topik hubungan dengan memberi contoh bapa beliau sendiri.

"Ayah saya seorang majikan tapi dia sangat menjaga hubungan baik dia dengan pekerja walaupun dia pekerja Indonesia". [t, + prop]

"Bonding tu adalah sangat baik dekat ladang ataupun kilang [+ val] [t, + norm]. Sampai lah hari raya pun diorang akan datang rumah dan beraya bersama"

Aina membuat dua Judgement tersirat berkaitan dengan etika bapanya dalam berurusan dengan pekerjanya. Dapat diandaikan bahawa ikatan antara bapanya dan pekerja adalah hasil dari kemesraan dan pengurusannya. Seperti disebutkan sebelum ini, 60\% dari semua Judgements yang dinyatakan adalah secara langsung (token). Ini dapat dijelaskan melalui fakta bahawa responden berkongsi pengalaman melalui aktiviti-aktiviti konkrit seperti lawatan dari rumah ke rumah, dengan memanfaatkan pengalaman mereka sebagai generasi ketiga FELDA. Ini seterusnya boleh menjurus kepada penilaian tersirat mengenai kemahiran dan kecekapan, seperti yang dapat dilihat dalam pernyataan Atikah berikut:

"Manfaat lain ... seperti peneroka reka ladang tu tempat mereka menternak haiwan" ( [t, + cap])

Kebijaksanaan peneroka dalam menjalankan dwi- perkebunan dapat ditafsirkan sebagai tanda Judgement positif atas kemampuan mereka sebagai petani.

Terdapat beberapa contoh Appreciation positif yang sering dilihat dari segi Penilaian (8 contoh) dan Komposisi ( 1 contoh). Responden berulang kali menekankan manfaat minyak sawit dan bagaimana ia mendorong kepada pertumbuhan industri sampingan / subsidiari seperti makanan, kosmetik dan pemeliharaan haiwan. Hasilnya ini dapat membantu mengukuhkan ekonomi serta mewujudkan 
peluang pekerjaan untuk penduduk tempatan. Kenyataan ini mencetuskan Affect positif, seperti yang ditunjukkan oleh Liana melalui minatnya untuk bekerja di industri ("Memang saya berminat [+sat] kalau ada peluang pekerjaan") Ini bersesuaian dengan tuntutan yang dibuat oleh Martin (2000) yang menyatakan bahawa sosialisasi ke dalam domain atau bidang melibatkan kedua-dua penyelarasan dengan amalan yang dilakukan dan hubungan dengan sikap seseorang terhadap amalan tersebut.

Soalan ketiga melihat kepada faktor-faktor di sebalik kurangnya minat dan penglibatan para belia di dalam industri ini.

\section{Soalan 3: Apakah faktor-faktor yang menyebabkan kurangnya minat dan keterlibatan di kalangangenerasi muda terhadap industri kelapa sawit?}

Secara umum, terdapat kekurangan minat dan keterlibatan di kalangan generasi muda terhadap industri kelapa sawit. Walaupun terdapat kekuatan yang dinyatakan sebelumnya, sikap negatif di kalangan belia ini adalah disebabkan oleh keadaan kerja fizikal industri yang kasar. Mereka mendakwa bahawa pekerjaan di sektor pertanian membebankan dan meletihkan (Norsida, 2008). Pendapat ini disokong oleh kajian Walsh dan Makaravy (2011) yang melaporkan bahawa pekerjaan perladangan dianggap sebagai pekerjaan 3D (Difficult, Dirty and Dangerous- Sukar, Kotor dan Berbahaya) oleh belia tempatan. Empat penilaian negatif telah diberikan secara langsung melalui contoh-contoh yang konkrit. Bekerja di ladang bermaksud perlu bekerja di bawah terik panas matahari. Hari-hari menjadi terlalu panjang dan memenatkan, sementara pendapatan pula tidak tetap kerana ia bergantung pada jumlah berat hasil dan harga pasaran minyak sawit.

"Untuk bekerja dekat kilang atau ladang, dia bekerja di bawah matahari kan, panas sikit. [t, - val]. Kalau ikutkan kerja biasa dia tujuh hingga lapan jam sahaja, tapi kalau untuk kelapa sawit ni dia kira ikut berapa biji buah kita dapat, berapa berat dia berapa, dia ikut atas satu buah berapa"

$[\mathrm{t},-\mathrm{val}])$

Sebilangan kecil Judgement dibuat secara langsung dan tidak langsung terhadap pemuda dan sikap mereka. Atikah menunjukkan Judgement negatif (kapasiti) ketika dia mengatakan 'pemuda kita ada banyak masalah' [- cap]. Penjelasan atau contoh masalah tidak dihuraikan, tetapi dapat disimpulkan bahawa tingkah laku bermasalah mungkin menjadi satu isu di kalangan remaja tempatan. Tambahan dari itu, Syahirah mengatakan bahawa orang muda pada masa kini adalah terlalu memilih dalam mencari pekerjaan ('faktor-faktor dia sebab emm pemuda zaman kini sangat memilih kerja' [- norm].

Hasil kajian dari Roslina et al. (2016), Norehan (2016) dan Mohamad Amizi et al. (2016) menyokong kenyataan ini dengan menyatakan bahawa kebanyakan belia tempatan lebih gemar bekerja di sektor perkilangan dan peruncitan berbanding dengan sektor pertanian dan perladangan. Ini mungkin disebabkan kerana mereka memiliki pendidikan dan kelayakan yang tinggi seperti yang dicadangkan oleh salah seorang responden di bawah ini.

'Saya rasa generasi sekarang ni terutama generasi kedua atau ketiga mereka dah mula mempunyai pendidikan $[t,+$ cap]jadi diorang semua berhijrah untuk menjadi lebih baik selain daripada menjadi buruh di kawasan pertanian'

Oleh itu mereka mencari jawatan / pekerjaan yang lebih baik dan yang memberi pulangan yang lebih. Kenyataan ini menyokong penemuan yang telah dibuat oleh Abdul Aziz \& Norhlilmatun (2013) yang mendakwa bahawa pertanian tidak dilihat sebagai alternatif yang menarik kerana pendapat konvensional bahawa pertanian menawarkan gaji yang rendah dan tidak menjanjikan masa depan yang cerah untuk pekerja. Tanda kapasiti positif ini akhirnya mendorong para belia untuk berhijrah ke bandar. 


\section{Soalan 4: Bagaimanakah cara untuk menarik minat generasi muda melibatkan diri dalam industri kelapa sawit?}

Kedua-dua tanda Appreciation positif dan negatif terhadap industri dapat dilihat melalui cadangan yang dikemukakan oleh responden. Liana mencadangkan agar kursus diberikan untuk meningkatkan kesedaran dan minat di kalangan belia ("hmm dia kerap melakukan kursus untuk anak-anak muda"). Kerana keadaan kerja yang sukar di industri [t, - val], Syahirah menyarankan agar memperkenalkan kaedah dan teknologi baru untuk bekerja di dalam bidang pertanian ("mungkin kita kena guna kaedah baru sebab kerja-kerja tu terlalu berat kalau nak buat" ). Ini sejajar dengan kenyataan yang dibuat oleh mantan Menteri Perusahaan Perladangan dan Komoditi yang mendesak institusi pengajian tinggi dan syarikat swasta untuk menyatukan sumber mereka dan memikirkan cara yang lebih efektif untuk mengambil buah kelapa sawit dari pokok dan kemudian menghantar ke kilang (The Star, 4 Feb 2017 ).

Pada masa yang sama, Syahirah juga mencadangkan untuk mewujudkan lebih banyak jawatan pentadbir kepada siswazah muda agar mereka diberi peluang untuk mendorong idea baru dan segar ke dalam sistem, dan menawarkan insentif pekerjaan serta memberi gaji atau elaun yang lebih tinggi.

"berikan diorang minat kepada kerja pentadbiran. Jadi, diorang boleh buat kerja di pejabat jadi diorang boleh boleh bagi idea untuk melakukan apa yang lebih bagus... kena beri macam insentif ataupun faedah, macam kita naikkan dia punya gaji ke ataupun kita bagi elaun bulanan yang tinggi..."

Farah juga mengemukakan ide yang baik ketika dia menyarankan untuk memperkenalkan program pengkhususan dalam bidang kelapa sawit di pusat-pusat pengajian tinggi dengan memberi fokus kepada penyelidikan dan infrastruktur misalnya.

"mewujudkan pengkhususan yang.. ataupun jurusan yang khusus dalam bidang kelapa sawit tidak kira lah dalam.. dari segi penyelidikan ke prasarana ke dan sebagainya"

Soalan berikut meminta pendapat responden mengenai insentif dan usaha kerajaan semasa.

\section{Soalan 5: Adakah kerajaan Malaysia memberikan insentif yang sesuai dengan usaha yang diberikan dalam industri kelapa sawit?}

Secara keseluruhan, kelima-lima responden menilai industri dan kerajaan secara positif melalui Appreciation secara langsung. Mereka memberi komen bahawa FELDA telah banyak membantu masyarakat peneroka melalui sokongan kewangan, biasiswa dan insentif kewangan secara one-off. Ini dilihat dapat membantu meringankan banyak beban keluarga mereka. Kerajaan juga telah memberikan latihan, kursus dan seminar mengenai minyak sawit kepada peneroka.

“...training pulak, banyak jugak training [t, +val] dulu dalam bidang perindustrian ni jugak pastu diorang juga ada bagi dekat peneroka tu sendiri tentang kesedaran menjaga pokok kelapa sawit tu, macam ikut kursus atau ceramah" [t, +val].

Namun, di sebalik kursus-kursus dan latihan-latihan yang diberikan, Farah mengungkap kapasiti negatifnya dengan mengakui bahawa dia tidak mengetahui apa-apa tentang insentif atau biasiswa yang ditawarkan oleh kerajaan dalam meningkatkan industri ini. Ini katanya disebabkan oleh kurangnya pendedahan industri, promosi dan insentif kepada masyarakat (penilaian-ve).

"Saya kurang mengetahui tentang insentif ataupun biasiswa ataupun apa sahaja yang dilakukan oleh pihak kerajaan Malaysia dalam membantu industri kelapa sawit [t, capl...kurang banyak la maksudnya tidak banyak diberikan jadi tiada pendedahan sebetulbetulnya tentang industri kelapa sawit ni” 
Atikah membuat penilaian negatif secara tidak langsung terhadap FELDA ketika dia menekankan tentang penukaran biasiswa FELDA yang telah menjadi pinjaman pendidikan ("Tapi rasa biasiswa dulu je ada pastu sekarang ni dah dimansuhkan" [t, - val]).

Walau bagaimanapun, FELDA telah membantu menyelesaikan $50 \%$ pinjaman mereka (t, + val). Appreciation negatif secara langsung telah diberikan oleh Aina kerana beliau tidak berpuas hati dengan syarat yang tinggi dan tidak masuk akal untuk mendapatkan biasiswa. Beliau berpendapat bahawa sangat sukar untuk mendapatkan tajaan dari FELDA atau MPOB kerana syarat yang diperlukan adalah PNGK 4.00 atau 9A dari pemohon.

"Adalah sangat susah untuk dapatkan tajaan pendidikan daripada pihak Felda ataupun mungkin MPOB [- val], sebab saya lihat, ketetapan ataupun requirement yang dia mintak adalah sangat tak masuk akal [- val]. Apa yang dia mintak adalah '4 flat' ataupun '9 A' sekurangkurangnya, '9 A+'."

Soalan terakhir mengungkai pendapat para belia mengenai potensi industri kelapa sawit pada masa depan.

\section{Soalan 6: Adakah industri kelapa sawitmempunyai potensi masa depanyang baik?}

Empat orang responden menyampaikan penilaian Appreciation yang positif mengenai potensi industri. Para belia ini berpendapat dengan penyelidikan berterusan dan teknologi yang terkedepan, industri ini boleh mengembang dan dapat meningkatkan kualiti hasil produk, yang akan menjuruskan kepada peningkatan permintaan produk. Ini dapat mewujudkan potensi ekonomi yang baik di masa hadapan untuk Malaysia, sebagai salah satu pengeksport minyak sawit terbesar di dunia. Kesannya, ini dapat menarik lebih ramai orang, khususnya penduduk tempatan melibatkan diri untuk bekerja dalam industri ini.

\footnotetext{
"Potensi dalam industri kelapa sawit ni masih boleh diteruskan dengan teknologi [ + val], mungkin kita boleh lebih berkembang, pastu ada banyak pengeluaran lagi [ + val] lepas tu keluarkan... keluarkan buah yang lebih bermutu [ + val] jadi kita mempunyai permintaan yang banyak $[+\mathrm{val}]$ jadi boleh menarik balik orang untuk pandang balik industri kelapa sawit ini" $[+$ sat].
}

Namun Liana memberi komen bahawa potensi ini hanya akan dapat direalisasikan sekiranya tenaga kerja industri ini tidak dimonopoli oleh pekerja asing.

"Ya kalau kelapa sawit ni tidak diambil alih oleh orang... pekerja asing" $[\mathrm{t}$, - reac $]$

Berdasarkan kepada data yang telah dikumpulkan, terdapat hanya $17 \%$ dari penilaian merujuk kepada Judgement (lihat Rajah 1). Berkaitan dengan potensi, Atikah membuat dua Judgement, secara langsung dan tidak langsung, ke atas dua generasi iaitu golongan belia dan peneroka generasi pertama. Beliau menjelaskan bahawa generasi pertama peneroka telah semakin berumur dan dengan itu tidak mempunyai tenaga yang cukup untuk menguruskan ladang. Malangnya, anak-anak mereka telah berhijrah ke bandar, mencari kehidupan yang berbeza dari ibu bapa mereka. Ini memberikan cabaran kepada kekuatan dan kelestarian industri. Namun begitu, beliau percaya bahawa generasi muda memiliki Kapasiti (+) untuk melindungi tanah yang mereka warisi dengan menempatkan tanah tersebut di bawah pengurusan FELDA.

"Tapi dengan keadaan sekarang ni peneroka pun dah lanjut usia [t, -cap] diorang pun dah tak larat nak uruskan perladangan [- cap] dan kebanyakan anak-anak FELDA pun dah berhijrah jadi saya rasa tanah ini boleh diselamatkan dengan cara mereka mewarisi balik tapi diserahkan kepada FELDA untuk mengurus" [ $\mathrm{t}$, +cap].

Secara keseluruhan, analisis ini telah mengetengahkan tiga aspek di mana penilaian responden memainkan peranan penting dalam menonjolkan kekuatan dan kelemahan industri dan komunitinya: 
1) Appreciation positif berhubung dengan faedah, potensi dan pengiktirafan dan 2) Appreciation negatif berkaitan dengan keadaan kerja yang sukar dan pekerjaan berkemahiran rendah dan 3) Judgement berhubung dengan golongan belia dan kurangnya minat dan kesedaran mereka mengenai potensi industri.

Apa yang dapat disimpulkan dari penemuan ini adalah industri kelapa sawit telah membantu meningkatkan ekonomi tempatan $(47+$ Appreciation $)$ dari masa lalu hingga sekarang dan telah menjadi sumber kehidupan utama bagi peneroka di 317 penempatan FELDA di seluruh negara, sejak FELDA dibentuk oleh Tun Abdul Razak pada tahun 1956 (The Malay Mail, 13 Jan 2016).

\section{Kesimpulan}

Berdasarkan kepada teori Appraisal Systemic Functional Linguistics, khususnya sistem Attitude, makalah ini mengemukakan analisis linguistik makna interpersonal (interpersonal meaning) yang diungkapkan oleh 5 belia FELDA terhadap industri kelapa sawit dalam 2 temubual kumpulan fokus. Analisis data menunjukkan yang responden menggunakan pelbagai jenis sumber interpersonal, menyatakan Attitude yang berbeza (positif dan negatif, secara langsung dan tidak langsung) ketika memberi komen mengenai pelbagai aspek dalam industri.

Analisis data telah mengetengahkan tiga aspek kekuatan dan kelemahan organisasi semasa dan komuniti. Kekuatan pertama melibatkan kelestarian industri dan bagaimana ia telah menyumbang secara signifikan kepada pertumbuhan ekonomi tempatan dan pengurangan kemiskinan luar bandar, serta memberikan manfaat kewangan dan sosial yang signifikan kepada masyarakat FELDA. Kesemua responden menyampaikan penilaian positif terhadap industri dari segi kesinambungan, kestabilan dan peranannya dalam menyokong penduduk tempatan, baik dari segi ekonomi mahu pun sosial. Kesudahannya mereka juga menyatakan keyakinan terhadap potensi masa depan kelapa sawit dengan merujuk kepada penyelidikan berterusan dan teknologi yang digunakan yang boleh meningkatkan kualiti produk, dan menyebabkan peningkatan dalam permintaan. Mereka merasakan bahawa ini dapat menarik lebih ramai penduduk tempatan untuk berminat dan melibatkan dalam industri ini. Sejak tahun 1917, industri kelapa sawit telah mewujudkan ribuan pekerjaan dan telah melakukan banyak usaha untuk membebaskan para peneroka dari kemiskinan di Malaysia, yang mengakibatkan kesejahteraan dan penambahbaikan kesihatan sosial (Kushairi et al, 2017). Selain itu, industri kelapa sawit juga membolehkan ribuan pekebun kecil menjadi pemilik tanah.

Di sebalik fakta-fakta positif ini, hanya seorang responden sahaja yang menyuarakan minatnya untuk bekerja di industri ini. Yang lain memperlihatkan kurang minat mereka di kalangan generasi muda, yang mengaitkannya dengan pendidikan tinggi, pekerjaan di bandar yang kompetitif dengan peluang pertumbuhan kerjaya yang lebih baik dan kurangnya dorongan dari ibu bapa peneroka. Faktor penting lain di sebalik kekurangan minat ini berpunca dari keadaan persekitaran bekerja di kilang kelapa sawit atau di ladang. Para belia ini percaya bahawa pekerjaan ini memerlukan kerja berjam-jam di bawah terik matahari. Sebilangan besar responden menekankan keadaan kerja yang sukar dengan penilaian negatif. Penilaian ini kebanyakannya adalah secara langsung melalui contoh konkrit yang diberikan, melalui pengalaman dan pemerhatian. Sentimen responden menunjukkan cabaran industri dalam mengembangkan kaedah baru dan moden untuk melibatkan belia dengan minyak sawit melalui teknologi dan media sosial. Para belia ini perlu menyedari hakikat bahawa dalam tempoh 30 tahun yang lalu, industri kelapa sawit telah berkembang dan para belia ini tidak lagi terbatas pada peneroka. Bank, syarikat insurans, perkapalan dan pengangkutan, saintis dan jurutera kini menjadi sebahagian daripada rantaian bekalan minyak sawit (The NST, 2017).

Kajian ini telah menunjukkan bagaimana para belia FELDA berhubung dengan, dan menyelaraskan atau tidak seiringan dengan industri kelapa sawit. Ulasan positif dan negatif responden terhadap organisasi, komuniti dan sifat kerja menyoroti pengalaman dan pemahaman mereka tentang apa ertinya menjadi sebahagian daripada komuniti FELDA. Mereka saling berhubungan dan terikat dari segi perasaan dan nilai yang dikongsi bersama berkaitan dengan pelbagai aspek industri. Pelbagai jenis sumber interpersonal yang digunakan oleh responden, telah mengungkai bagaimana generasi muda 
memilih jalan yang berbeza untuk memenuhi aspirasi mereka dan juga bagaimana, selama bertahuntahun, industri kelapa sawit dan masyarakatnya di Malaysia sangat berdaya tahan dan dapat menyesuaikan diri dengan pelbagai perubahan dan cabaran.

\section{Rujukan}

Ajzen, I. (1993). Attitude Theory and the Attitude-behavior Relation. In New Directions in Attitude measurement. Berlin. Walter de Gruyter.

Ajzen, I., \& Fishbein, M. (1980). Understanding Attitudes and Predicting Social Behavior. Englewood-Cliffs, NJ. Prentice-Hall.

Baker, C. (1988). Key Issues in Bilingualism and Bilingual Education. Clevedon, Avon: Multilingual Matters.

Eagly, A. H., \& Chaiken, S. (1993). The Psychology of Attitudes. Fort Worth, TX: Harcourt

Ferdous A., Er, A.C \& Halima B. (2015). Malaysian Oil Palm Industry: Prospect and Problem. Journal of Food Agriculture and Environment, 13(22), 143-148

Frick, M., Birkenholz, R., Gardner, H. \& Matchmes, K. (1995). Rural and Urban Inner City High School Students: Knowledge and Perceptions of Agriculture. The Journal of Agricultural Education, 36(2), 44-53

Fuzirah H., Kesumawati A.B \& Siti Hamin S. (2019). Sikap dan Motivasi Generasi Muda terhadap Industri Minyak Kelapa Sawit. E-Bangi Journal of Social Sciences and Humanities, 16(4), 1-17

Gardner, R.C. (1985). Social Psychology and Second Language Learning: The Role of Attitudes and Motivation. London. Edward Arnold

Kushairi, A, Singh, R and Ong-Abdullah, M. (2017). The Palm Oil industry in Malaysia: Thriving with Technologies. Journal of Oil Palm Research, 29(4), 431-439

Malaysia Human Resource Statistic. 2013. https://www.dosm.gov.my. (accessed 5 April 2019)

Martin, J. R. \& Rose, D. (2003). Working with Discourse: Meaning Beyond the Clause: Continuum Intl Pub Group.

Martin, J. R. \& White, P. R. R. (2005). The Language of Evaluation: Palgrave Macmillan Basingstoke.

Martin, J.R. (2000). Beyond Exchange: Appraisal Systems in English. In S. Hunston \& G.Thompson (Eds.), Evaluation in Text: Authorial Stance and the Construction of Discourse. 142-175. Oxford: Oxford University Press.

McGuire, W.J. (1985). Attitudes and Attitude Change. In: Lindzey, G. and Aronson, E., Eds., Handbook of Social Psychology, 2(3), 233-346. Random House, New York.

Mohammad Amizi A, Norehan Abdullah \& Jamal Ali (2016). Perception of Local Youths in Malaysia East Coast Region towards the Career Prospect in Oil Palm Plantation.

Norehan Abdullah \& Siti Aznor Ahmad, and Mohamad Amizi Ayob (2016). Labour Force Participation of Rural Youth in Plantation Sector of Northern Peninsular Malaysia. Jurnal Ekonomi Malaysia, 50(2), 83-92.

Norsida Man. (2008). Persepsi terhadap Pertanian dalam Kalangan Belia Tani dan Keperluan Pendidikan Pertanian. J. Pembangunan Belia Malaysia, 1, 99-114.

Roslina, K. Mohd Amizi, Norehan Abdullah, Jamal Ali, \& Siti Aznor Ahmad. (2016). Job Satisfaction among Malaysian Youth Working in the Palm Oil Plantation Sector: Analysis of Attraction and Repulsion Factors. Proceeding - 3rd Kuala Lumpur International Agriculture, Forestry and Plantation. May 21 - 22, 2016.

Saifuddin A. (2017). Better education for FELDA youth. http://pnews.theedgemarkets.com/article/second-sphere-better-education-felda-youth. [Accessed 3 July 2018].

Siti Hamin S., Kesumawati A.B \& Fuzirah, H. (2018). Attitudes \& Motivation of the Young Generation towards the Palm Oil Industry. Mediterranean Journal of Social Sciences, 10(1).

The Malay Mail. (13 Jan 2016). Felda Schemes a Legacy of Tun Razak. (accessed 3 April 2019)

The NST (4 Feb 2017). 100th year industry: Creating Value for Palm Oil. (accessed 3 April 2019)

Walsh, J. \& Makararavy,T. (2011). Cambodian Migrants in Thailand: Working Conditions and Issues. Asian Social Science, 7(7), 23-29. 